\title{
高分子物質の透濕性（I）
}

さきに高分子膜の氣体の透過性について竹田政民氏が 本誌1)に興味ある綜說をのせ，理論的興味の中心がなん であるかを明快に解說された。すなわち一般の氣体及び 蒸氣の透過の機構，膜中の拡散現象と透過性，膜に対す る溶解性と透過性, 高分子の一般的性質と透過性の関係 を述べられてもる。

水蒸氮の高分子膜透過現像も名台万几上記一般論の一 部と考え, 総括的には他の氣体または蒸氣と比較してゆ かねばならないのは当然である。上記綜說にも各処に水 蒸氣透過についてふれて岗るが，紙面の都合で具体的な 実例を割愛してあるので，筆者点焦点を高分子物質の透 濕性にのみしぼって数值などを檢討してみることにす る。

数值を取り拆う上に和いてすぐ問題になるのに, 透濕 性をあらわす售量の單位である。

透濕莧像を示す一般式は定常狀態で

$$
Q=P \cdot \frac{\left(p_{a}-p_{b}\right)}{l} \cdot t \cdot s
$$

$Q$ ほ透過した水蒸氣の重量またに签積, $p_{a}$ 及び $p_{b}$ はそれぞれ膜の両面の水蒸氣圧， $l$ は膜の厚さ， $i$ 時 間, $s$ は膜の面積, $P$ 以透濕係数。

いまC.G.S. 單位で透濕俰数をあらわをと $P$ の單位は

$$
\frac{\mathrm{g} \cdot \mathrm{cm}}{\mathrm{cm}^{2} \cdot \mathrm{sec} \cdot \mathrm{cm} \mathrm{Hg}}
$$

となる。 $\mathrm{cm} \mathrm{Hg}$ の代りに $\mathrm{mm} \mathrm{Hg} ; \mathrm{cm}^{2}$ の代りに $\mathrm{m}^{2}$; $\sec$ の代りに hr, $24 \mathrm{hr} ; \mathrm{cm}$ の代りに $\mathrm{mm}, 0.1 \mathrm{~mm}$; $\mathrm{g}$ の代りに mol cc.; などをとるようである, その組み合 せにより数值が变ってくるわけであるので，相互に換算 表でせつくっておくと便利であうら。

電氯学会またりで單位を統一しょうとしている。

包裝関係の J.I.S. やまたフメリカの A.S.T.M. な ぞでは，測定條件を指定して透濕量を汸かっているため 上記の單位は用いていない。

例えば日本では 1 平方米, 24 時閒またりの透濕量, す なわち

$$
\frac{\mathrm{g}}{\mathrm{m}^{2} \cdot 24 \mathrm{hr}}
$$

をとり,アメリカでは 100 平方インチ， 24 洔閪をたり の透濕量, すなわ台

$$
\frac{\mathrm{g}}{100 \text { in }^{2} \cdot 24 \mathrm{hr}}
$$

を採用しているゆ六，同一條件では

$$
(4) \times 16=(3)
$$

カツト： ポリェチレン紙製造装虽
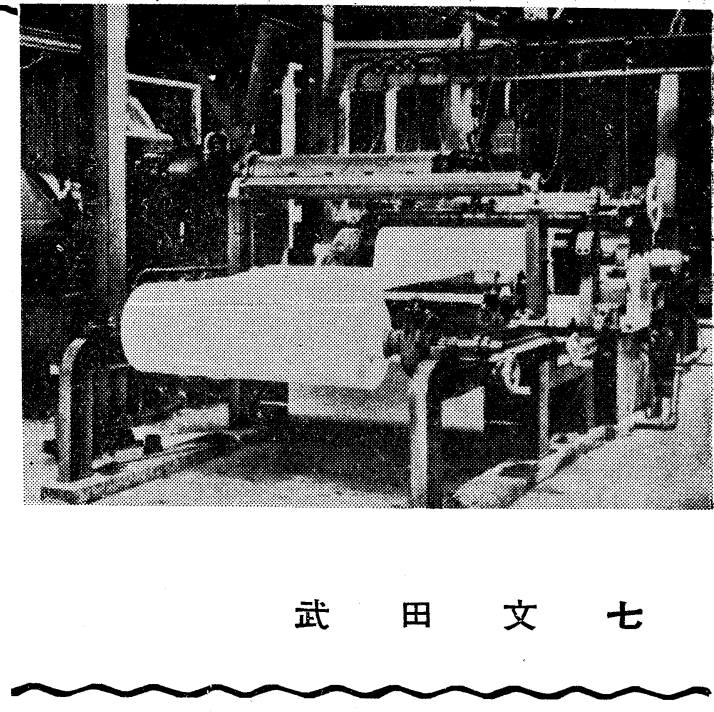

となる。

J.I.S.の話がでたついでに, 透濕量測定に関する規 格で尔, 日本でもアメリカでるカップ法を採用している。

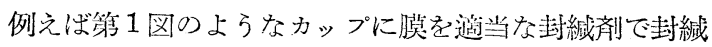
しカップ內に深乾燥塩化カルシウムを入れ，それを $40^{\circ} \mathrm{C}$

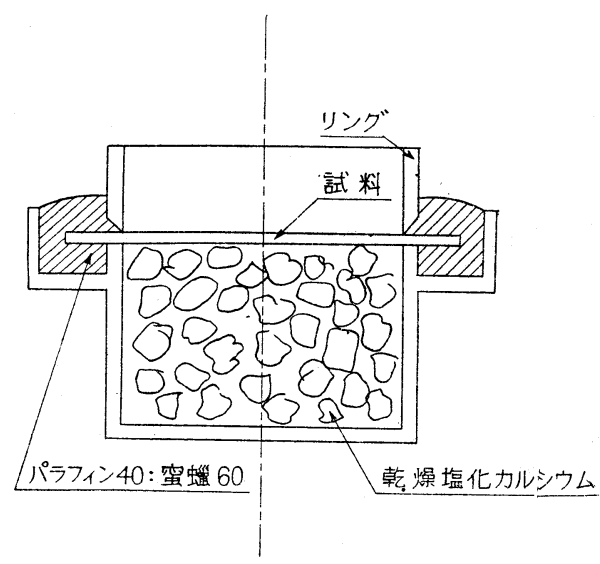

第 1.図透濕カッ プ

で約 $90 \% \mathrm{R} \cdot \mathrm{H}$ の恒溫恒濕槽の中に入れて, カップの 重量增加を時間ごとにはかるのが J. I. S Z. 0208 の装領 である。また，アメリカで用いられている A.S.T.M. 法とか General Food 法の装領も上記と殆えど同じで ある。ただ $100^{\circ} \mathrm{F}\left(37.8^{\circ} \mathrm{C}\right)$ 約 $90 \% \mathrm{R} \cdot \mathrm{H}$ という條件で ある。

比較のために單位を統一する必要があるので，ここで は透濕係数は C. G.S. 單位をとり, $\mathrm{g} \cdot \mathrm{cm} / \mathrm{cm}^{2} \cdot \mathrm{sec} \cdot \mathrm{cm}$ $\mathrm{Hg}$ をとる。また透濕量をあらわずとき $\mathrm{g} / \mathrm{m}^{2} \cdot 24 \mathrm{hr}$ をとってゆくことにする。個々のデーターには測定條件 を明記することが必要である。

データーを整理してみると，條件もまちまちであり， かなりやっかいである。ことに重量法でやったのと圧力



Vol. 3 [251] 
てめる。な技測定方法の詳細を舂くことが目的でないの で，他の交献1を参照されたい。

な物，固体中の搪散に関しては Barrer2) の著書が有 名である。詳細な一般的取扱法が記載されている。高分 子物質に対する水蒸姚透過の現象もその一部分として述 べられてめるので，是非一竌する必裂がある。

\section{§1. 高分子膜の透濕係数及び透濕量の数值}

われわれが理論的興味と同時に, 实際的な面からも知 りたいのは，专る高分子膜がどれほど濕氯を透すか，そ して他のものと比較して透濕性が多いか少ないかという ことである。

第 1 表には主なる高分子膜について，從來得られてい る值をならべてみた。

配列後の考察になるべく便利なよらにしておいた。 第1表に用いた單位は，透濕係数は朁述のごとく $\mathrm{g} \cdot \mathrm{cm}$ $/ \mathrm{cm}^{2} \cdot \mathrm{sec} \cdot \mathrm{cm} \mathrm{Hg}$ である。また透濕量は包裝材料など と，廣く用いられている單位と比較し易くするために， その測定溫度において, $90 \%$ 相対濕度差のある場合，

厚さ $0.1 \mathrm{~mm}, 1$ 平方米の高分子膜党，24時間に透過 する水蒸氣の $\mathrm{g}$ 数である。すなわち $\mathrm{g} \cdot / \mathrm{m}^{2} \cdot 24 \mathrm{hr}$ であ る。

後述するごとく, 透濕係数は厚さ, 水蒸氣圧差, 溫度 により簧ってくるので，一つの條件の測定值から出した 透濕係数から，他の條件の透濕量を換算するの心もち 几正確な数值を出しえない。乙かし量的な比較をするに は役立つ。をた, 溫度 $10^{\circ} \mathrm{C}$ 上梨で大体 2 倍透濕量が上 昇するとして，簡略に他の溫度の透濕量の大体の檢討を つけてみることも許されるであろう。

第 1 表には畽極性重合体, ゴム系物質, 極性重合体, 共重合体，纎維素誘導体の別に配列してみた。 $\mathrm{OH}$ 基な どの影響がいかに大きいかポリビニルアルコール，醀酸 繊維素などをみればただちにわかる。

\section{§2. なせ高分子膜を濕氣が透過するか}

多数の研究の結果, 現在までもっとも考えられる透濕 の機構は次のようである。おなわち濕氣が高分子膜を透 過するのは三つの異った原因によるとするのである。

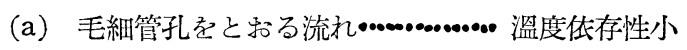

（b）高分子膜自体をと扔る活性拡散…溫度低存性大

(c) (a) と（b）の中間で, 高分子膜中の水蒸氣に対 する吸着能のある活性点が影響する活性拡散……

溫度依存性大

（a）の過程は，高分子膜を製造したときからつくら れてある裂目または毛細管的孔の存在を含及, その平均 の孔の廣さは拡散していく水蒸氣分子の直径より大きい 場合に扢こる。氣相中の水蒸氣分子は自由な運動をして いる。その結果, 個々の分子はかかる毛細管に入りら
る。毛細管中では不規則に毛細管の壁で反射され，氣体 狀態の特性の一つに非常に類 似せるブラウン運動を行 う。この “自由”拡散の総括的効果として, 水蒸氣分 子の本均自由行程と, 毛細管の本均值径の比によって, Poiseuille の流れによってあらわされるか, Kundsen 拡 散によってあらわされるかがきまってくる。これはいい かえれば, 拡散水蒸氣の蒸氣圧により, 高分子膜の孔に よって影響される。毛細管の壁で何回も反射された後, 移動水分子は最後に他の側に出てくる，すなわち透過す るのである。

この既存の裂目（大小さまざままり，高分子物質のい わゆる結晶の表面にそって存在するようなるのもあり， ピンホール的なるのるめる）学と和る非活性拡散におよ

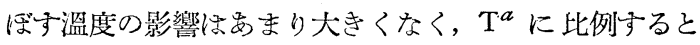
考えられる。ここに a ほ 0.5 附近であり, 水分子の大 きさ，毛細管の性質によってきまる。

第 2 の機榗である高分子自体をと抢る水蒸氣分子の活 性拡散はしかし（a）とは異る性質のものである。簡單 のため，高分子膜佉均一で芯あるか鎮状分子の配列ので たらめな狀態, すなわち disorderd state にあると仮 定しよう。すると，それは非常に高い秥性の液体または ガラス狀態と考えてよろしい。氣相中の水分子はその自 由な運動の結果, 膜の境界面にぶつかる機会か浿えられ る。多くの場合，それらは彈性的に反射される。乙かし ある場合には，それらは高分子膜の最初の数原子層に入 りこむであろら。そして不規則に物質をとおり，拡散し はじめる。この場合の水分子の狀態は（a）の場合と異 り, 理想氯体の條件と合致せず，むしろ非常に粘性の 高い夜体に溶解された粒子のブラウン運動をしてい る状態にめると考えられる。液体の粘性の概念, 特に

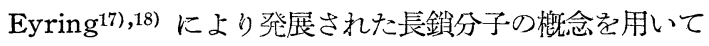
考察できる。移動水分子はある位蹎の周りで擬彈性振動 を行い, 周四の鎖の七グメントの運動に上り一つの “孔” が形成されると（その位置の近くで）水分子はこの孔の 中に移動する。その場所で, また，概水分子はふたたび 出る時間振動した後, 次の孔に移る。かくして最初存在 しないのであるが，高分子物質の內部のセグメントの熱 振動によりつぎつぎつくられた"孔”をと特って, 溶解 水分子は移動する。

かかる孔を形成する確率结比較的小さく, 女る水分子 隹比較的長い間待って一つの孔から次の孔に移る。

熱力学的にほ孔惊，孔形成にあずかるエネルギー及び エントロピーにより特徵ずけられる。そしてこの二つの 量は "活性”拡散の速度々之の溫度依存性から得られ る。孔の $1 \mathrm{~mol}$ についてあらわされたこれら二つの量 は $\mathrm{H}_{2} \mathrm{O}$ と塩酸ゴム (pliofilm) の例では約 $12 \mathrm{Kcals} / \mathrm{mol}$ がエネルギーで $10 \mathrm{cals} / \mathrm{mol}{ }^{\circ} \mathrm{K}$ がエントロピー差で女 る。 
第 1 表高分子膜 透濕係数

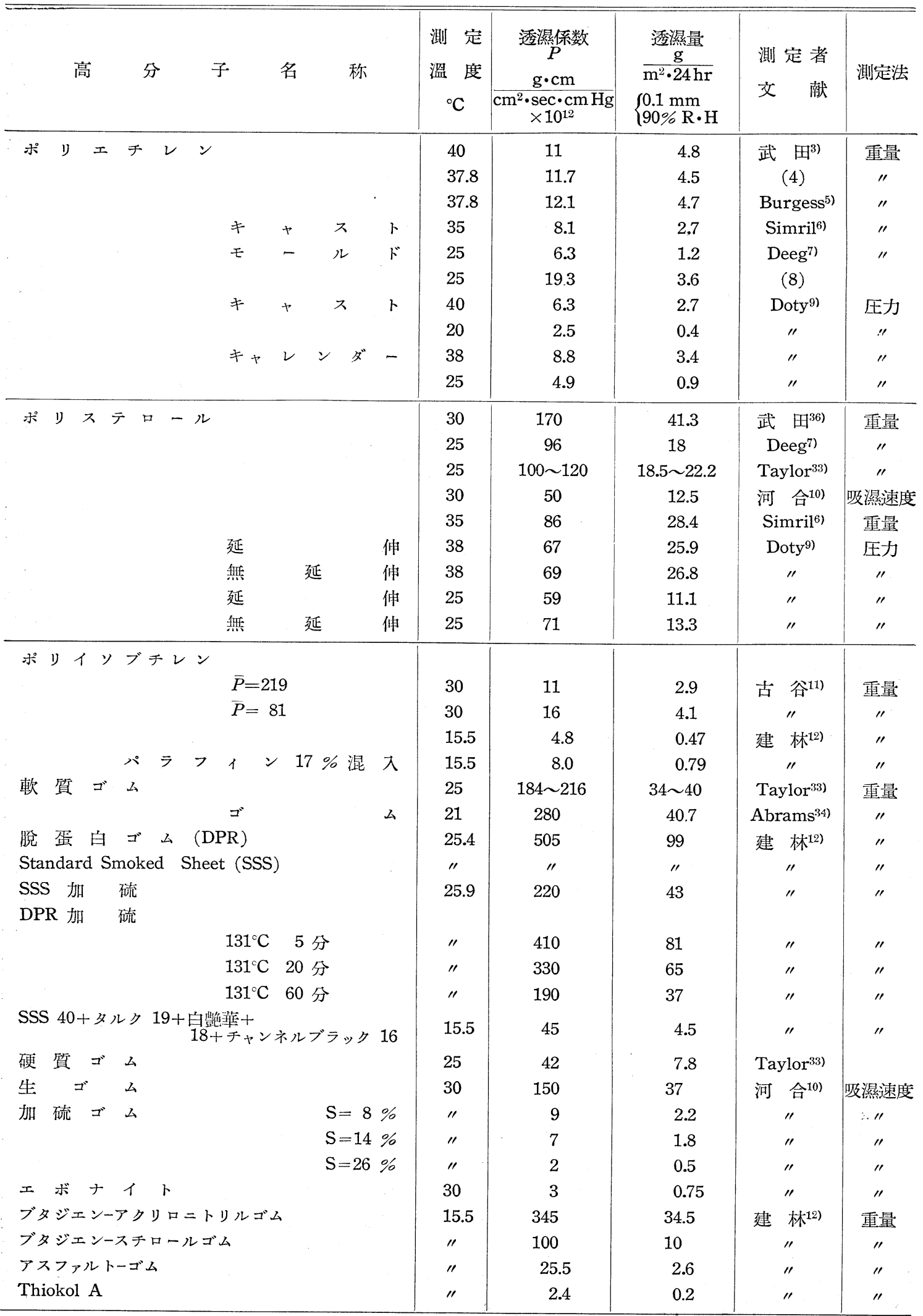




\begin{tabular}{|c|c|c|c|c|c|}
\hline 高 & $\begin{array}{c}\text { 測 定 } \\
\text { 溫 度 } \\
{ }^{\circ} \mathrm{C}\end{array}$ & $\left|\begin{array}{c}\frac{\text { 透濕係數 }}{P} \\
\frac{\mathrm{g} \cdot \mathrm{cm}}{\mathrm{cm}^{2} \cdot \mathrm{sec} \cdot \mathrm{cm} \mathrm{Hg}} \\
\times 10^{12}\end{array}\right|$ & $\begin{array}{l}\frac{\text { 透濕量 }}{\mathrm{g}} \\
\frac{\mathrm{m}^{2} \cdot 24 \mathrm{hr}}{20.1 \mathrm{~mm}} \\
90 \% \mathrm{R} \cdot \mathrm{H}\end{array}$ & $\begin{array}{l}\text { 測 定者 } \\
\text { 交 献 }\end{array}$ & 測定法 \\
\hline $\begin{array}{l}\text { プライオフィルム } \\
\text { ライイファ } \\
\text { プライオフィルム }\end{array}$ & $\begin{array}{l}15.5 \\
25 \\
\prime \\
40 \\
40 \\
25\end{array}$ & $\begin{array}{c}5.8 \\
73 \\
6.1 \\
\\
10 \\
12.7 \\
1.0\end{array}$ & $\begin{array}{r}0.6 \\
13.5 \\
1.1 \\
\\
4.6 \\
5.6 \\
0.09\end{array}$ & $\begin{array}{c}\text { 建 林 }{ }^{12)} \\
\text { Taylor }{ }^{33)} \\
\quad " \\
\text { 武 } \mathbb{⿴ 囗 十 ~}^{16)} \\
\text { Doty }^{14)}\end{array}$ & $\begin{array}{l}\text { 重量 } \\
\text { " } \\
\text { " } \\
\text { " } \\
\text { " } \\
\text { 圧力 }\end{array}$ \\
\hline $\begin{array}{l}\text { ポリビニルアルコール } \\
\text { ポリメチルアタリート } \\
\text { 酢酸ビニル } \\
\text { ポリメチルメタアクリレート } \\
\text { ポリアクリロニトリル } \\
\text { 塩化ビニル }\end{array}$ & $\begin{array}{c}30 \\
35 \\
30 \\
\prime \prime \\
\prime \prime \\
25 \\
30 \\
25 \\
35 \\
30 \\
\prime \prime \\
25 \\
30 \\
25 \\
\prime \prime\end{array}$ & $\begin{array}{c}6000 \\
1000 \\
1400 \\
700 \\
1000 \\
840 \\
400 \\
111 \\
33.3 \\
29 \\
33 \\
12 \\
100 \\
9.3 \\
6.2\end{array}$ & $\begin{array}{c}1490 \\
341 \\
345 \\
175 \\
250 \\
156 \\
100 \\
21 \\
11 \\
7.3 \\
8.4 \\
2.4 \\
25 \\
1.7 \\
1.1\end{array}$ & 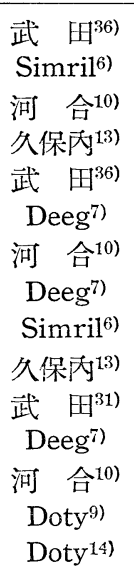 & $\begin{array}{c}\text { 重量 } \\
\text { " } \\
\text { 吸濕速度 } \\
\text { 重量 } \\
\text { " } \\
\text { " } \\
\text { 吸濕速度 } \\
\text { 重量 } \\
\text { " } \\
\text { " } \\
\text { " } \\
\text { " } \\
\text { 吸濕速度 } \\
\text { 压力 } \\
\text { " }\end{array}$ \\
\hline 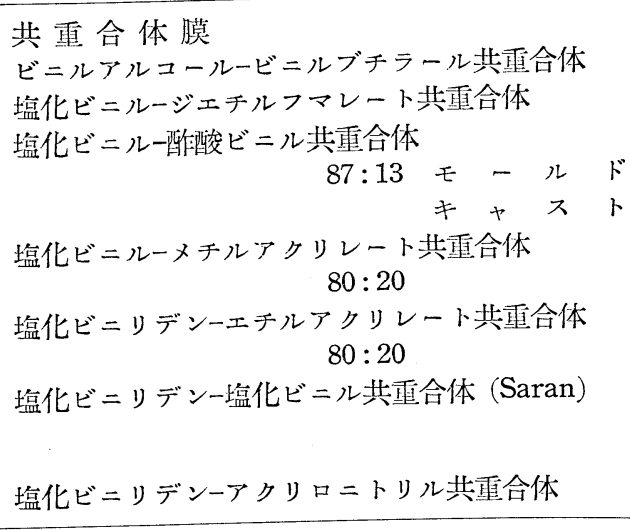 & $\begin{array}{l}35 \\
\prime \prime \\
37.8 \\
25 \\
\prime \prime \\
\\
30 \\
\\
\prime \prime \\
37.8 \\
40 \\
25 \\
35\end{array}$ & $\begin{array}{l}48 \\
21.9 \\
2.27 \\
2.27 \\
0.16 \\
1.5\end{array}$ & $\begin{array}{l}12.3 \\
\\
5.5 \\
0.9 \\
1.0 \\
0.03 \\
0.5\end{array}$ & 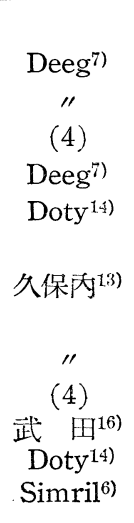 & $\begin{array}{c}\text { 重量 } \\
\text { " } \\
\text { " } \\
\text { " } \\
\text { 圧力 } \\
\text { 重量 } \\
\text { " } \\
\text { " } \\
\text { " } \\
\text { 压力 } \\
\text { 重量 }\end{array}$ \\
\hline 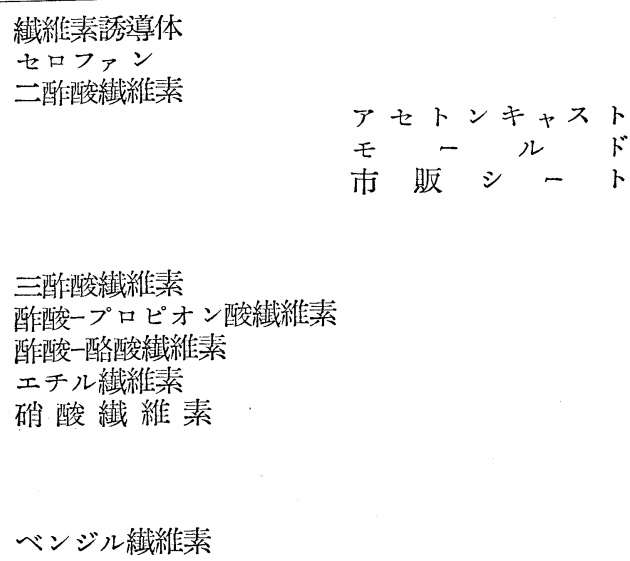 & $\begin{array}{l}30 \\
\prime \prime \\
25 \\
\prime \prime \\
\prime \prime \\
35 \\
30 \\
25 \\
\prime \prime \\
\prime \prime \\
\prime \prime \\
40 \\
30 \\
25 \\
30 \\
\prime \prime\end{array}$ & $\begin{array}{r}3000 \\
5450 \\
8000 \\
3160 \\
1070 \\
1800 \\
430 \\
1960 \\
2770 \\
1420 \\
2100 \\
1600 \\
960 \\
6100 \\
430 \\
680\end{array}$ & $\begin{array}{r}760 \\
1380 \\
1500 \\
595 \\
200 \\
595 \\
110 \\
368 \\
520 \\
267 \\
394 \\
740 \\
240 \\
1150 \\
110 \\
170\end{array}$ & 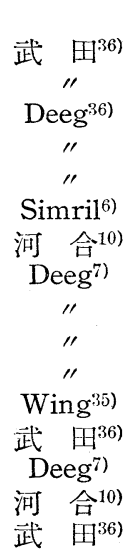 & $\begin{array}{c}\text { 重量 } \\
\text { " } \\
\text { " } \\
\text { " } \\
\text { " } \\
\text { " } \\
\text { 吸濕速度 } \\
\text { 重量 } \\
\text { " } \\
\text { " } \\
\text { " } \\
\text { " } \\
\text { " } \\
\text { " } \\
\text { 四濕速度 } \\
\text { 重量 }\end{array}$ \\
\hline
\end{tabular}


最後に上記二つの間の中間の機構と思われる第 3 の機 構がある。以前の ${ }^{19)}$ また最近の多くの研究によれば, 高 分子, 纎維素岕るい恬气の誘導体心いわゆる內部表面積 を有している。それが水分子に対して近ずくこと交許 し，吸着がおこる。吸着するということは非常に猍いス リットや裂目の存在を唔示し, その壁は高、吸着力の多 くの中心，ななわち活性点または高度の分子閐作用力の ある点を有している。例えば水分子が繊維素膜中を拡散 するときには，繊維素膜表面また经內部の（內部に括い て表面に配列している）-OH 基功かる高い水分子結 合能力の点となる。るし一つの水分子があるスリットの 中に入ると，ただちにこれら-OH 基の一つに吸着され

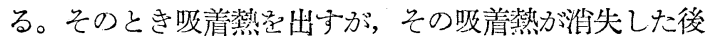
は，この - -OH 基の近くで振動する。そして熱摇動に上 り脫着するに必要な十分のエネルギーを獲得すると，ス リットの中に再蒸発する。そして吸着の点には寄與しな いが, 壁と彈性衝突起した後, 他の活性点に吸着され, そこにしばらくの時閒とどまる。結局このような吸着, 脫着を繰返して他の側に通り拔ける。これる“活性” 拡散と考えられるが，年でにりくられたスリットや孔を 活性点を媒介として移動していくという差暴が步る。

これる活性のエネルギーやエントロピーで特徽ずけら れるが，その量性前と異った意味を有与る。水分子 1 mol に対して 8000 14000 cals の活性化ェネルギーほ 吸着された分子が活性点から蒸発するに必要なエネルギ 一であり，活性化エントロピーは個々の水分子が自由狀 態と吸着狀態に扔いてとるなう, 振動, 回轉などの自由 度の差に基くものである。特徽として溫度低存性が大で 岁る。

この場合，両者の量は高分子の不規則なセグメント運 動とば関係なく，拡散水分子と，ある活性点との閒の特 別な作用に関係する量である。

高分子の透過に抢よ棌す結晶性の実際効果综まだあま り十分に研究されていないが, 高分子の結晶領域, 非結 晶領域の相対的関係之水分子透過 との関係心 重要であ る。Langmuir と Schaefer ${ }^{-0)}$ の單一の結晶化された分 子厴をと括る蒸発速度が無定形部分をと扮るときの蒸発 速度よりもいちちるしく小さいという研究は重要な暗示 となる。

しかし实際の透濕現象は上記三つのいずれの場合に上 るかをはっきり定めることはなかなかむずかしいことで 岕る。多くの場合活三つの原因が一緒になって扢こるの で流なからか。從ってエネルギー量の測定, エントロ ピー量の測定か機㭔解明の一つの助けとなる。

また，活性基，物質の結晶性，內部表面積など他の方 法で得られた高分子の諸性質と結びつけて考えねばなら ないことはもらろんであり，それら諸性質を知ること が，透濕現象の解釈には必ず必要となるのである。

\section{§3. 透濕係数の溫度变化}

現在考えられている透濕の機構は大体上記の考え方が 中心となっている。從って透濕係数 $P$ の溫度变化を調 べ, $\log P$ と $1 / T$ の傾斜から活性化エネルギー $E_{P}$ を 求めることが重要となる。一般式は（1）にも紹介され ているごとく

$$
\begin{aligned}
& P=P_{0} e^{-E_{P} / R T} \\
& D=D_{0} e^{-E_{D} / R T} \\
& S=S_{0} e^{-\Delta H / R T} \\
& P=D \cdot S \\
& E_{P}=E_{D}+\Delta H
\end{aligned}
$$

\begin{tabular}{|c|c|c|}
\hline 重 合 体 & $\begin{array}{l}\text { 活性化 } \\
\text { エネル゙ー } \\
E \text { cals/mol }\end{array}$ & $\begin{array}{c}25^{\circ} \mathrm{C} \text { 透濕係数 } \\
\frac{\mathrm{g} \cdot \mathrm{cm}}{\mathrm{cm}^{2} \cdot \mathrm{sec} \cdot \mathrm{cm} \mathrm{Hg}} \\
\times 10^{12}\end{array}$ \\
\hline ポリステロール & 0 & 71 \\
\hline $\begin{aligned} \text { 塩化ビ } & =ル ・ \text { 酶酸 } \\
\text { ビ } & =ル \text { 共重合体 }\end{aligned}$ & 2350 & 26 \\
\hline ポリ塩化ビニル & 4000 & 9 \\
\hline $\begin{array}{l}\text { ポリエチレン } \\
\text { (カレンダー法) }\end{array}$ & 8000 & 4.9 \\
\hline $\begin{array}{l}\text { ポリエチレン } \\
(\text { キャスト法 })\end{array}$ & 10200 & 3.2 \\
\hline 塩酸ゴム & 12800 & 1.0 \\
\hline ポリ塭化ビニリデン & 17500 & 0.16 \\
\hline
\end{tabular}

である。

P. M. Doty ${ }^{9,21)}$ が $E_{P}$ を圧力法より求めた結果は第 2 表のごとくである。

第 2 表 透濕の活性化エネルギー

また Simrilb) が重量法にてポリェチレンにて求めた 結果は $6750 \mathrm{cals} / \mathrm{mol}$ である。

Doty 等第 2 表加ら次の票柄を結論している。

(a) 第 2 表の前三つは非結晶性 ${ }^{22)}$ ，ポリエチレンは $3 / 4$ が結晶性 ${ }^{23)}$, 最後の二つ(結晶度高(24),25) ことがわ かっているが，EP がそれにつれて多くなることは結晶 性が透過性に対して抵抗となる。

（b）キャレンダ法でりくった膜がキャスト法でつく った膜より $P, E P$ が大きいことは不均一部分が多いた めである。

(c) $P$ の順序に $E P$ がなっているが,$P=P_{0} e^{-E_{P} / R T}$ 上り求めた上述の $E_{P}$ と $\log P_{0}$ とが直線的関係にある ことを示し，化学反應速度式との類似性からその解䣋を 統計的方法で試みた。

上述のことからるわかるごとく結晶性と活性化エネル ギーとの関倸を求めてみることは大切である。これと関 連してゴムでは結晶化する $0^{\circ} \mathrm{C}$ 以下では $E P$ が $30 \mathrm{Kcal} /$ $\mathrm{mol}$ で，それ以上では $10 \mathrm{Kcal} / \mathrm{mol}$ と明らかに異り,轉 移点の存在を明示できる。 
第 3 表 高分子重合体の $E_{P}, E_{D}, \Delta H$

\begin{tabular}{|c|c|c|c|c|}
\hline 重合 & $\mid \begin{array}{c}\text { 透濕の活性 } \\
\text { 化エルギー } \\
E_{P} \\
\text { cals } / \mathrm{mol}\end{array}$ & $\begin{array}{c}\text { 溶解熱 } \\
\Delta H \\
\Delta H \\
\text { cals/mol }\end{array}$ & \begin{tabular}{|c} 
拡散の活性 \\
化エネルギー \\
$E_{D}$ \\
cals $/ \mathrm{mol}$
\end{tabular} & $\begin{array}{c}40^{\circ} \mathrm{C} の \text { 唀濕係数 } \\
\frac{\mathrm{g} \cdot \mathrm{cm}}{\mathrm{cm}^{2} \cdot \mathrm{sec} \cdot \mathrm{cmHg}} \\
\times 10^{1:}\end{array}$ \\
\hline ポリビニルブチラール & -2100 & -13000 & 10900 & 144 \\
\hline 酶酸セルローズ & 0 & -12000 & 12000 & 900 \\
\hline ポリビニルアルニール & 2300 & -12000 & 14300 & 720 \\
\hline ナイロン & 2800 & -10500 & 13300 & 72 \\
\hline 塩酸ゴム & 6300 & -11900 & 17200 & 5.4 \\
\hline ポリエチレン & 8000 & -11200 & 19200 & 5.4 \\
\hline $\begin{array}{l}\text { 塩化ビニリデンーアク } \\
\text { 洪重合体 }\end{array}$ & 10300 & -9900 & 20200 & 1.26 \\
\hline
\end{tabular}

Plast. 27, 95 (1950)

7) G. Deeg: Mod. Plast. 22, 155 (1944)

8) Bakelite Co. のカタログ

9) P. M. Doty, W. H. Aiken and H. Mark: "Temperature dependence of water vapor permeability" I. E. C.Aug. 789 . (1946)

10)河合䚬次郎：“絕緣材料の吸 濕々電氣的性質”，日立幣作所 創立 10 周年紀念論文集

11）古谷進：“ポリイソブチレン 混和物㕫濕性”, 電氣通信研. 穴所成果報告第 366 号 Aug. (1953)

12）建林建司：“有機材料の透水. 性に関する研究”日本ゴム協

$\log P_{0}$ と $E_{P}$ の直線的閣係に可塑剤なしの線型高分子. 物に限って成立すること年いいるが，可塑化された重 合体や, 網狀棈造妾有子る重合体, 水分子と特別相互作 用の女るような重合体（例えばセロファン）については この直線関係は成り立たない。

また Doty 等は圧力法により $P$ 及び $D$ を求めて (その求め方 (1)), それから $S$ 出出して溫度变化を求め

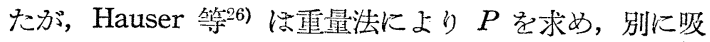
着量湘定より $S$ を求めて $P=D \cdot S$ の式より $D$ を出し た。そして $25^{\circ} \mathrm{C}$ 及び $40^{\circ} \mathrm{C}$ の測定值からそれぞれ, $E_{P}, E_{D}, \Delta H$ を出した。その結果を第3表に示した。

$E P$ の大小《 $E_{D}+\Delta H$ によりきまるわけで，䝫酸緎 維素で $E_{P}=0$, 從って溫度变化がない。しかし溫度变 化がないといっても必ずしも非活性拡散とに限らないい であることは $E_{D}$ と $\Delta H$ の符号が逆になっているため に，うら消しているからである。現象解明つとき $E_{P}$ の 內容をよく考えてみなければならない理由である。

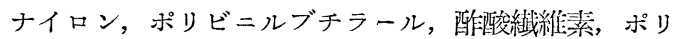
ビニルアルコールは EP の少いことからもおかるごとく 溫度による透濕係数の变化は小さい。すなわちこれらの

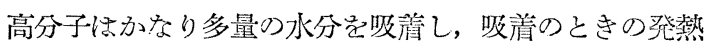
が拡散に用いられる熱とバランスし合うためである。い まの場合機精としてば一應（c）の場合が主として支 配していると思われる。(次号完結)

(東京大学理工学研究所)

\section{交献}

1）竹田政民：“高分子膜の氣体の透過性”, 高分子, 2 突 35 (1953)

2) R. M. Barrer: Diffusion in and through Solids Cambridge at the University Press. (1951)

3）武田文七：日化誌 74290 (1953)

4) "Saran coated paper", Modern Packaging, Sep. 117 (1951)

5) L. M. Burgess and L. F. Swell: "Polyethylene coated paper", Modern Packaging, Apr.187 (1950)

6) L. Simril and A. Herschberger: "Permeability of polymer films to organic vapors", Mod. Plast. 27, 97 (1950)

"Permeability of polymer fulms to Gases", Mod.
会誌 26 然 264 (1953)

13）久保內良彥, 山本連：通研月報 3 埈 744 (1950)

14) P. M. Doty, W. H. Aiken and H. Mark: "Water. vapor permeability of organic films" 1.E.C. $\mathbf{3 6}$, 686 (1944)

15）久保內良彥：未発表

16）武田文七：“最近》防濕材料”, 機械の研究 5 叁: 1 号 (1953)

17) H. Eyring: J. Chem. Phys. 4, 283 (1936)

18) Glasstone, Laidler and Eyring: "Theory of Rate Process", New York, Mcgraw-Hill Book Co., (1941)

19) W. Kaelberger and H. Mark: Z. Phys. Chem., 139, 151 (1928)

20) I. Langmuir and I. Schaefer: J. Franklin Inst., 235, 119 (1943)

21) P. M. Doty: “Diffusion of water vapor through polymers", J. Chem. Phys. 14, 244 (1946)

22) K. H. Meyer: "High Polymeric Substances New York," Jnterscience Publishers.

23) E. C. Raine, R. B. Richards and H. Ryder: Trans. Farad. Soc., 4156 (1945)

24) C. W. Bunn and E. V. Garner: J. Chem. Soc. 454 (1942)

25) W. C. Goggin and R. D. Lowry: I. E. C. 34 327 (1942)

26) P. M. Hauser and A. Douglars Mclaren: "Per meation through and sorption of water vapor by high polymers", I. E. C. Jan. 112 (1948).

27) A. M. Thomas. "Moisture permeability, diffusion and sorption in organic film-forming materials". J. App. Chem. 1 (1951)

28）武田文七：日化誌 74 癹 126 (1953)

29）武田文七：日化誌 74 坌 207 (1953)

30) A. E. Korvezee and E. A. J. Mol : "Diffusion of water vapor through high polymeric membranes", J. Pol Sci. 2, 371 (1947)

31）武田交七：日化誌 74 蓲 550 (1953)

32）久保內, 芦川：通研月報

33) R. Taylor, D. Herrmann and A. Kemp: I.E.C. 28, 1255 (1936)

34) A. Abrams and W. Chilson : Paper Trade J. 91 T.S. 193 (1930)

35) H. Wing: I.E.C. 28786 (1936)

36) 武田交七：日化誌 72 怣 602 (1951) 